\title{
11. BENTHIC FORAMINIFERS AT SITE 397: FAUNAL FLUCTUATIONS AND RANGES IN THE QUATERNARY
}

\author{
Gerhard F. Lutze, Geolog. Institute University Kiel, Olshausenstr. 40/60, 2300 Kiel, West Germany
}

\begin{abstract}
Cyclic fluctuations of benthic foraminifers are not restricted to the youngest Pleistocene, but continue throughout the Pleistocene part of the section (137 m thickness) and into the late Pliocene. They are correlated with similar fluctuations in the planktonic foraminiferal assemblage, reflecting surface-water changes. Accordingly, changes in the Atlantic deep water circulation, believed to be responsible for the benthic fluctuations, must have begun in the late Pliocene/early Pleistocene. A zonation of the Pleistocene is tentatively proposed, enabling separation of the middle/late Pleistocene from the early Pleistocene by means of benthic foraminifers.
\end{abstract}

\section{INTRODUCTION AND METHODS}

Cyclic changes of benthic foraminifers in deep-sea cores have been reported by Streeter (1973), Lutze (1977), and Lutze, Sarnthein, et al. (this volume). Benthic foraminifers seemingly reflect drastic changes in Atlantic deep water circulation, which in turn are related to the well-known changes of the surface water during cool phases. This hypothesis needs much more refinement. Moreover, it is not known whether these cyclic changes are restricted to the glacial Pleistocene or even to the late Pleistocene (isotopic stage 1-5). DSDP Site 397 (off Cape Bojador, northwestern Africa; $2900 \mathrm{~m}$ water depth) offers a unique opportunity to extend the study of benthic fluctuation to the middle and early Pleistocene. Based on the extremely high rate of sedimentation, even the relatively low sampling density of one sample per section (i.e., per 15,000 years) would guarantee detection of the majority of cool and warm maxima, if they exist.

A further objective was to determine vertical ranges of important benthic species in order to identify potential guide fossils which might allow a local zonation of the Pleistocene.

The study is based on 111 samples, which were washed on a $63 \mu \mathrm{m}$ sieve. Only the $>250 \mu \mathrm{m}$ was statistically evaluated ("foram counts"), to avoid problems involved with changing amounts of allochthonous faunal components, which are more frequent in the finer fractions. Most samples were $15 \mathrm{~cm}^{3}$ in size. They usually contained between 80 and 150 tests, which were referred to some 60 species. Dominant species and species of stratigraphical or ecological importance were illustrated (Plates 1 to 3 ). A more conventional taxonomy was applied, based mainly on Phleger et al. (1953) and Parker (1964). Taxonomical remarks are given in the plate explanations.

To characterize faunal fluctuations related to cool or warm phases, the species were arranged in the same faunal groups used in the study of Meteor Core 12329
(Lutze, 1977). In this core, a very good correlation was found between a warm indicative group of benthic species and the climatic curve derived from planktonic foraminifers by Pflaumann (1975). To accentuate the fluctuations and to allow convenient comparison with other curves, the total proportion of this "warm" benthic species was expressed in percentages of both, the "warm" and the "cool" species group (whereas percentages of all other species were ignored). The resulting curve is called the warm benthic foraminifers (WBF) curve. "Cool" species are: Pyrgo murrhina, Cibicidoides wuellerstorfi, Uvigerina peregrina, and Globobulimina hoeglundi. WBF species are: Laticarinina pauperata, Cibicidoides kullenbergi, C. robertsonianus, Cibicidoides sp. 1, Hoeglundina elegans, and Bulimina aculeata.

\section{FAUNAL FLUCTUATION}

The general trend of faunal fluctuation is outlined in Figure 1 and is similar to that observed in the youngest Pleistocene Meteor Core 12309 of the same locality; see Lutze et al., this volume). Uvigerina/Globobulimina-maxima alternate with the WBF-assemblage peaks (mainly Cibicidoides sp. sp. and Hoeglundina). The fluctuations continue down to the late Pliocene. A total of about twenty warm maxima is marked by peaks of the WBF-curve (Figure 2).

Consequently, fluctuations in bottom water conditions, which are responsible for such drastic changes, must have existed throughout the entire time span under discussion here. This must be treated as a minimum estimate of the number of fluctuations, due to a sampling density of one sample per section $(150 \mathrm{~cm})$ which covers a time interval of roughly 10,000 to 18 ,000 years.

\section{Comparison With $\delta_{18} \mathrm{O}$ Isotope Curve}

The isotope curve given by $\mathrm{Cita}$ and Shackleton (this volume, $\delta^{18} 0$ based on benthic foraminifers) was compared with the WBF-curve as explained above 


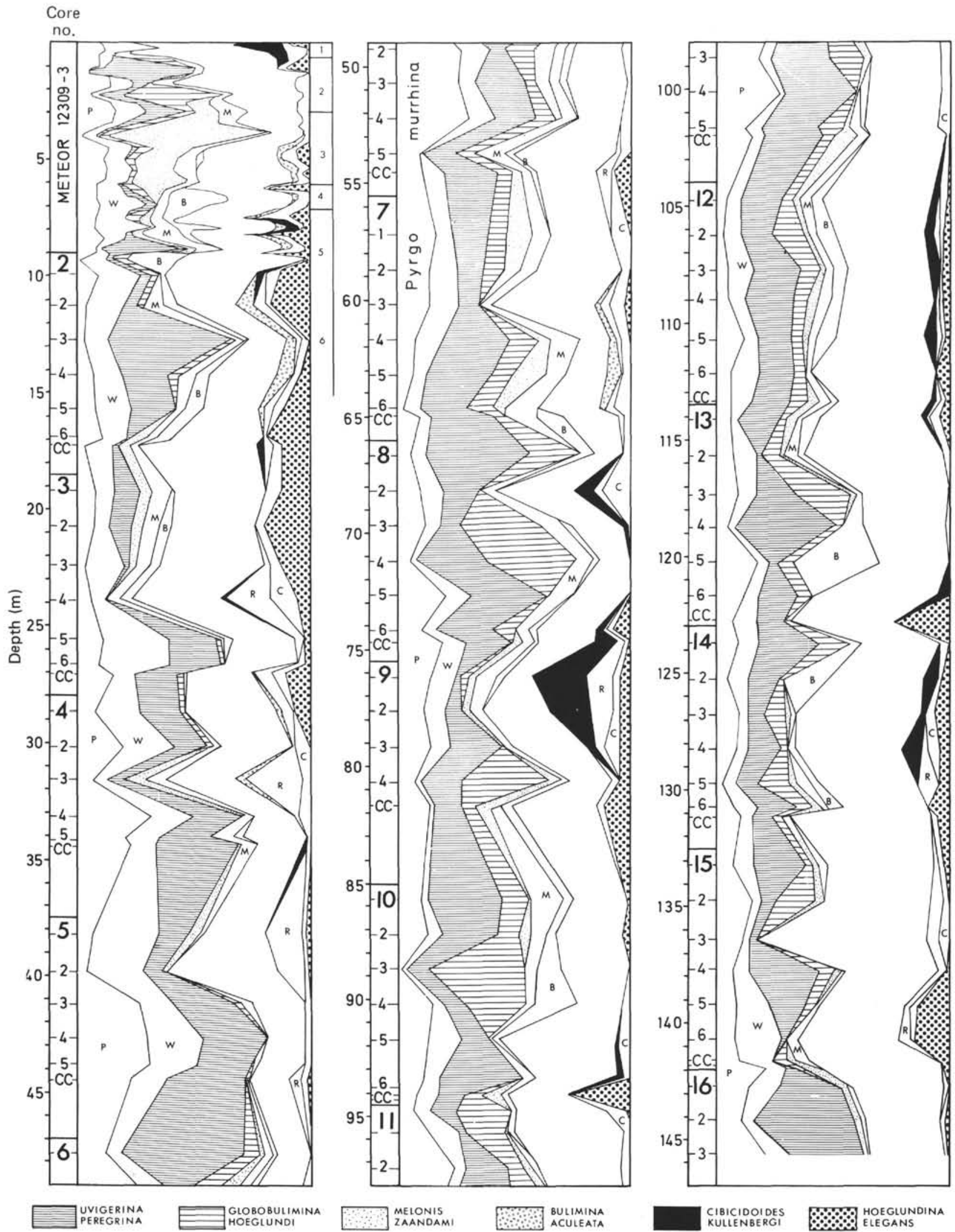

Figure 1. Fluctuation of benthic foraminifers $(<250 \mu \mathrm{m}$.), cumulative percentage diagrams. Note the entirely different pattern observed in the top 10 meters, due to a higher sampling density in Meteor piston Core 12309. $P=$ Pyrgo murrhina, $W=$ Cibicidoides wuellerstorfi, $M^{5}$ Melonis pompilioides, $B=$ Bulimina striata, $R=$ Cibicidoides robertsonianus, $C=$ Cibicidoides $s p .1$. 


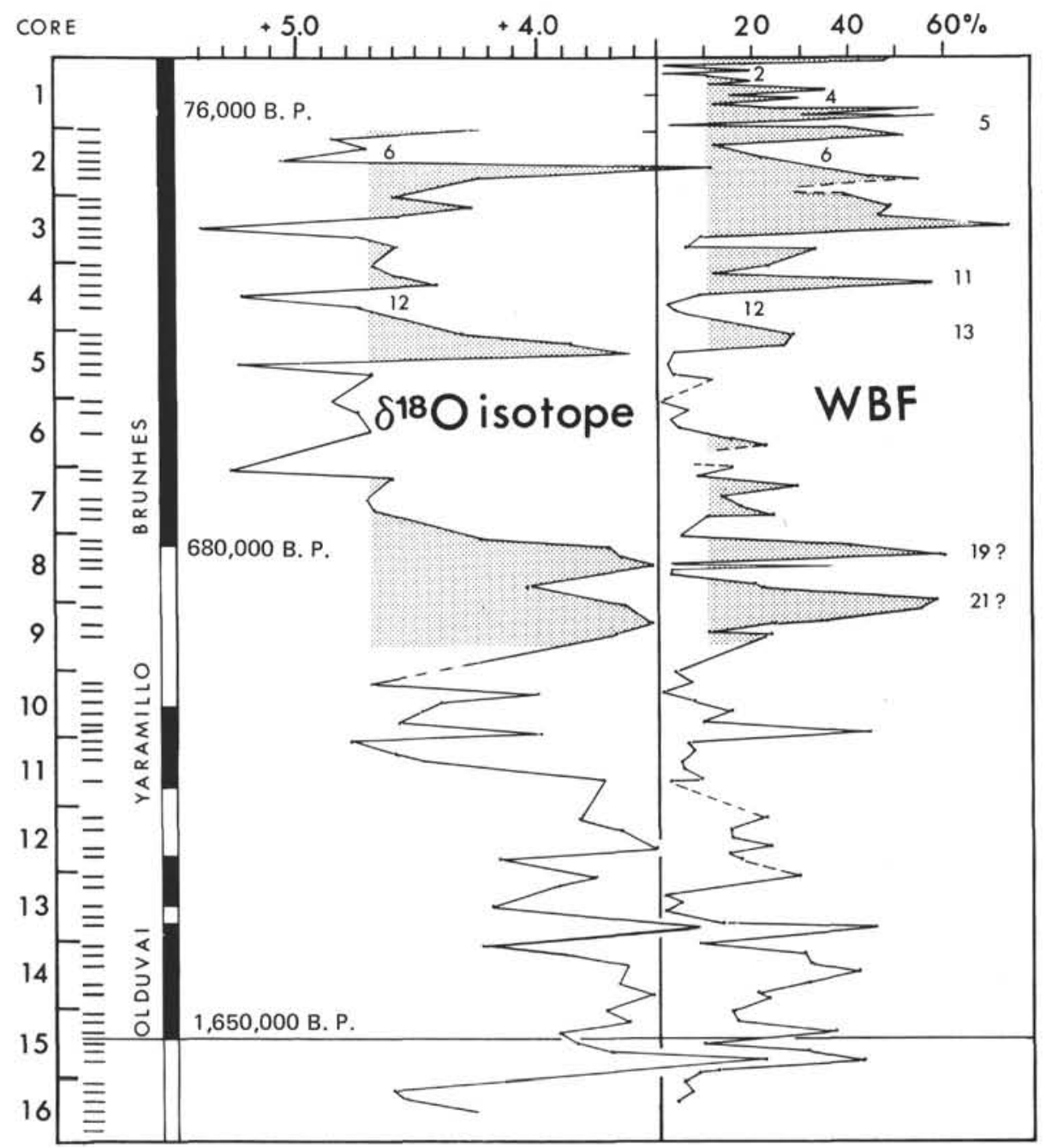

Figure 2. Comparison of $\delta^{18} \mathrm{O}$ isotope curve and the WBF curve ("warm benthic foraminifers"'). The isotopic curve was taken from Cita and Shackleton (this volume). The WBF curve is based on benthic foraminifers, but different samples (see text).

(Figure 2). Both curves show approximately the same number of warm peaks and, in addition, similar positions of extended "cooler" periods. However, no strict peak for peak correlation is possible and several isotopic peaks correspond with depressions in the WBFcurve. The correlation is slightly better in the early Pleistocene (Cores 10 to 16, Figure 3 ) but is weak in the late Pleistocene. This is partly due to differences in sampling positions. Shackleton's samples were usually taken 30 to $40 \mathrm{~cm}$ above the samples referred to in this study, which is equivalent to approximately 3000 to 4000 years. Distinctive shifts of the isotopic curve from cool towards warm may occur during such short intervals, as has been shown in Meteor Core 12309. To substantiate this explanation, an additional set of samples was studied from Cores 397-8 and 9 (new samples at 0.35 and $1.10 \mathrm{~cm}$, original samples at $0.70 \mathrm{~cm}$ ). The result is shown in Figure 4 with the two distinctive "warm" peaks (old position: broken line) separating into several peaks.
The discrepancy between warm isotopic values and "cool" foraminiferal evidence as found in Section 8-4 can now be explained by a "new" peak in lower Section 8-3 and upper 8-4. There is no doubt that an increased sampling density ( $20 \mathrm{~cm}$ distance) would give a resolution similar to that of Meteor Core 12309. It would result in the slopes of all peaks being much steeper and additional peaks being detected. Therefore, isotopic stage numbers (Shackleton and Opdyke, 1973) are applied only tentatively in Figure 2.

\section{Correlation With Planktonic Foraminiferal Trend}

The comparison with climatic evidence as indicated by planktonic foraminifer was restricted to the densely sampled interval (Cores 8 and 9) and only the $>250$ $\mu \mathrm{m}$ fraction was used. A simple measure was found by calculating the percentage of typical tropical species from the sum of these and Globorotalia truncatulinoides, which is a typical "transitional species" (Bé and Tolderlund, 1971). Tropical species used in this 


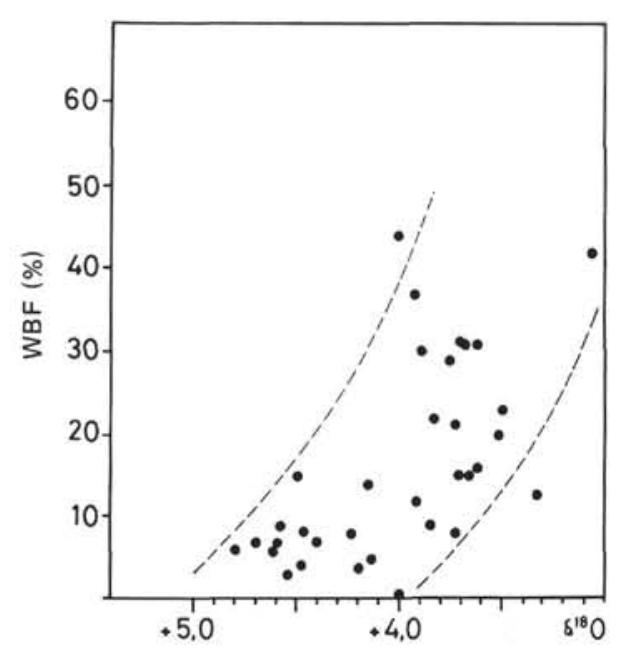

Figure 3. $\delta^{18} \mathrm{O}$ isotopic values (Cita and Shackleton, this volume) versus WBF percentages, early Pleistocene (Cores 10 to 16). Fairly well correlated in contrast to the middle Pleistocene. Cool isotopic values usually refer to $W B F$ percentages lower than 15, warm isotopic values correspond with $W B F$ percentages between 15 and 45 .

study were Globorotalia cultrata and G. tumida, Pulleniatina obliquiloculata, and Globigerinoides sacculifer.

Figure 4 clearly demonstrates that both planktonic and benthic foraminifers follow the same trend of climatically induced cycling. The correlation between the benthic curve (WBF) and the planktonic curve is even better than in Meteor Core 12309 (Figure 5, $r=0.82$ ).

\section{RECENT DEPTH DISTRIBUTION, DISCUSSION}

Benthic foraminiferal cycles and their possible origins have recently been discussed by Streeter (1973) and Schnitker (1974). New, detailed information has been reported recently by Streeter (1976; and May personal communication, 1977). He suggests that conditions typified by the present day shifted repeatedly to glacial situations such that the northern sources of oxygen-rich deep water were reduced or absent. During these periods oxygen-poor deep waters originated in the south. This "Pacific mode" of circulation is characterized by high frequencies of Uvigerina peregrina. The ecological importance of this species was emphasized by Lutze (1977, Leg 41) and is demonstrated again in the present study: $U$. peregrina and Globobulimina hoeglundi characterize cool periods. However, if Streeter's explanation is correct, the present distribution of these low-oxygen tolerant species should not be strictly correlated with depth, since the oxygen content of North Atlantic deep water decreases with latitude (Dietrich et al., 1975, pl. 4; Wattenberg, 1939). The recent depth distribution of Uvigerina peregrina, as outlined on Figure 6 shows that the vertical boundaries of the distribution pattern and high abundances in low-oxygen areas support the hypothesis of Streeter.

\section{DISPLACED BENTHIC FORAMINIFERS}

The amount of displaced benthic foraminifers decreases with an increase in grain size. Significant proportions of allochthonous species were found in the 63 to $125 \mu \mathrm{m}$ fraction, fewer (up to $3 \%$ ) in the 125 to 250 $\mu \mathrm{m}$ fraction. However, the true proportion of displaced specimens is difficult to estimate, since information on the taxonomy and the natural habitat of most species under discussion here is insufficient. The majority belongs to the genus Bolivina. Lutze shows that certain smaller Bolivinas B. pseudoplicata, B. difformis, and B. variabilis are true shelf dwellers. These species, at least in the smaller size fraction, must be considered allochthonous. They form considerable proportions in seven test samples selected to represent "cool" and "warm"' maxima. The values for cool phases are about 14 per cent, those for warm intervals vary between 5 and 11 per cent. However, a more detailed study is required to find out whether these differences may be generalized. In the late Pleistocene (see Lutze et al., this volume) must higher proportions of allochthonous species were reported (up to $25 \%$ ) but no significant difference between cool and warm intervals was noted.

Grain-by-grain transport, as discussed by Bein and Fütterer (1977), is suggested as being responsible for the displacement of these foraminifers. It is possible that sediment accumulation rates at continental margins are strongly influenced by this type of transport.

\section{BIOSTRATIGRAPHY}

The vertical ranges of the dominant species which are larger than $250 \mu \mathrm{m}$ are given in Figure 7. Several typical Pliocene species disappear with the beginning of the Brunhes magnetic epoch: e.g., Stilostomella lepidula, Stilostomella sp. sp., Pleurostomella brevis, Parafrondicularia advena, Orthomorphina sp. 1, and Ellipsoglandulina laevigata. At this time, the first major cooling of Atlantic bottom water is also indicated by the isotopic record of Cita and Shackleton (this volume). Consequently this clear biostratigraphic differentiation is probably not locally restricted, which might therefore permit a subdivision of the Quaternary in this region. This would be exceptionally useful, since planktonic foraminiferal marker fossils in the Pleistocene have not proven to be reliable in all cases. It is also useful that the resulting boundary is equivalent to the early middle Pleistocene boundary as defined in the literature.

The subdivisions of the Pleistocene proposed here are named NB-5 and NB-6 according to the "faunal units" used in the Site 397 Report, this volume). A further subdivision is tentatively suggested: the first appearance of Bolivina quadrilatera may enable the separation of NB-5b from NB-5a. A conspicuous feature within NB-6 (i.e., the middle and late Pleistocene) is the beginning of continuous occurrences of Hoeglundina elegans in the upper part of Core 4. This is used to differentiate between NB-6a and NB-6b. An additional subdivision might be possible with the last occurrence of $B$. quadrilatera, separating NB-6c from NB-6b. This latter "boundary" would correspond with the beginning of the 


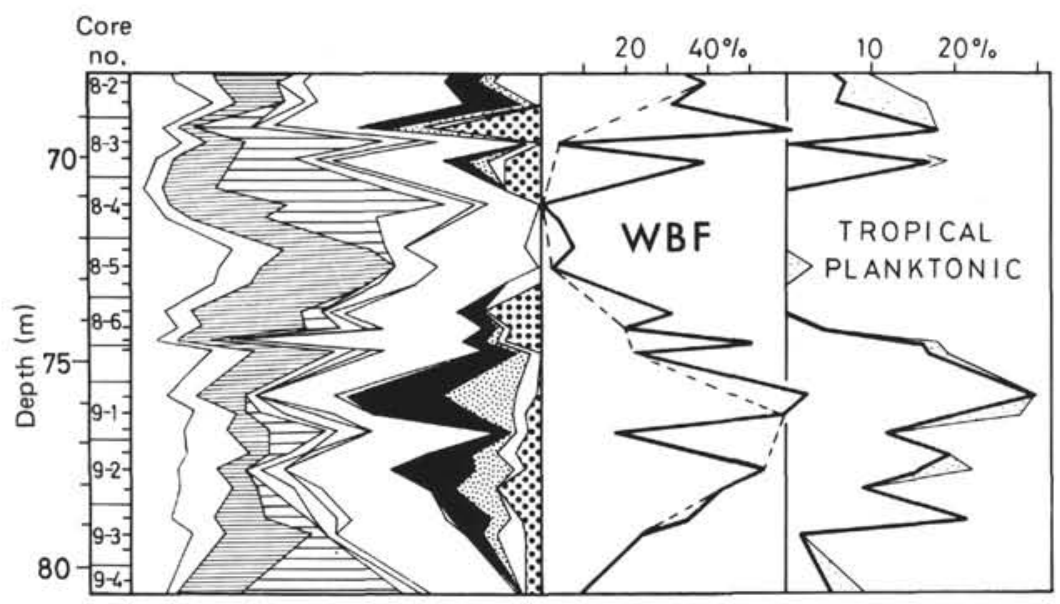

Figure 4. Changes in the observed fluctuation pattern after additional sampling. Compare with the same interval on Figure 1. On the right: Correlation between the WBF-curve and tropical planktonic foraminifers (see text). Broken line: WBF curve after first sampling (I sample per section).

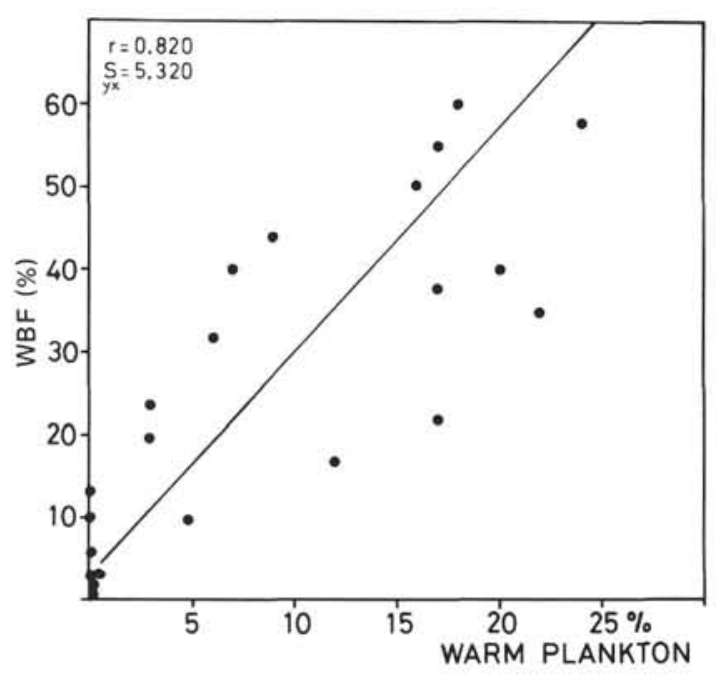

Figure 5. Tropical planktonic foraminifers versus WBF percentages, Cores 8 and 9. Without Globigerinoides sacculifer.

Pleistocene. However, the somewhat scattered occurrence of $B$. quadrilatera does not suggest a more than local significance of this sub-unit.

\section{ACKNOWLEDGMENTS}

I would like to express my thanks to several friends and collegues: S. Streeter, Lamont, provided access to unpublished manuscripts and valuable information. N. Shackleton made his oxygen-isotope curves available (see Cita and Shackleton, this volume). M. Sarnthein, Kiel, and U. Pflaumann, Kiel, discussed the results and made many suggestions. Financial support from the "Deutsche Forschungsgemeinschaft," Bonn, is appreciated.

\section{REFERENCES}

Bé. A. W. H. and Tolderlund, D. S., 1971. Distribution and ecology of living plantonic foraminifera in surface waters of the Allantic and Indian oceans: London (Cambridge University Press).

Bein, A. and Fütterer, D., 1977. Texture and composition of continental shelf to rise sediments off the northwestern coast of Africa: An indication for downslope transportation, Meteor-Forschungs-Ergebnisse, C, v. 27, p. 46-74.

Caralp, M., Lamy, A., and Pujos, M., 1970. Contribution a la connaissance de la distribution bathymetrique des foraminiferes dans le golfe de Gascogne Revista Espan. Micropaleontal, v. 2, p. 55-84.

Dietrich, G. Kalle, K.,Kraus, W., and Siedler, G., 1975. Allgemeine Meereskunde: Berlin-Stuttgart (Bornträger).

Lutze, G. F., 1977. Neogene benthonic foraminifera from Site 369, Leg 41. In Lancelot, Y., Seibold, E., et al., Initial Reports of the Deep Sea Drilling Project, v. 41: Washington (U. S. Government Printing Office), p. 659-666.

, in press. Depth distribution of benthic foraminifers on the continental margins of NW Africa, "Meteor" Forsch-Ergebnisse, C.

Parker, F. L., 1964. Foraminifera from the experimental Mohole drilling near Guadalupe Island, Mexico, J. Paleontol., v. 38 , p. $617-636$.

Pflaumann, U., 1975. Late Quaternary stratigraphy based on planktonic foraminifera off Senegal. "Meteor" Forsch. -Ergebnisse, C, v. 23, p. 1-46.

Phleger, F. B., Parker, F. L., and Peirson, J. F., 1953. North Atlantic foraminifera. Rept. Swedish Deep-Sea Exped., v. 7, p. 3-121.

Pujos-Lamy, A., 1973. Repartition bathymetrique des foraminiferes benthiques due golfe de Gascogne, Revista Espan. Micropaleontol., v. 5, p. 213-234.

Schnitker, D., 1974. West Atlantic abyssal circulation during the past 120,000 years, Nature, v. 248 , p. 385-387.

Shackleton, N. J. and Opdyke, N. D., 1973. Oxygen isotope and paleomagnetic stratigraphy of equatorial Pacific Core V 28-238: oxygen isotope temperatures and ice volumes on a $10^{5}$ and $10^{6}$ year scale, Quat. Res., v. 3, p. 39-55.

Streeter, S. S., 1973. Bottom water and benthonic foraminifera in the North Atlantic-glacial-interglacial contrasts, Quat. Res., v. 3, p. 131-141.

1976. Deep water benthic foraminiferal faunas in the Atlantic during the Late Pleistocene-the significance of Uvigerinid peaks, Am. Geophys. Union Trans., v. 57, p. 258 (abstr).

Wattenberg, H., 1939. Atlas zu: Die Verteilung des Sauerstoffs im Atlantischen Ozean. Wissenschaftliche Ergebnisse der Deutschen Atlantischen Expedition auf dem Forschungs- und Vermessungs-schiff "Meteor," 19251927, Band IX, Atlas. 

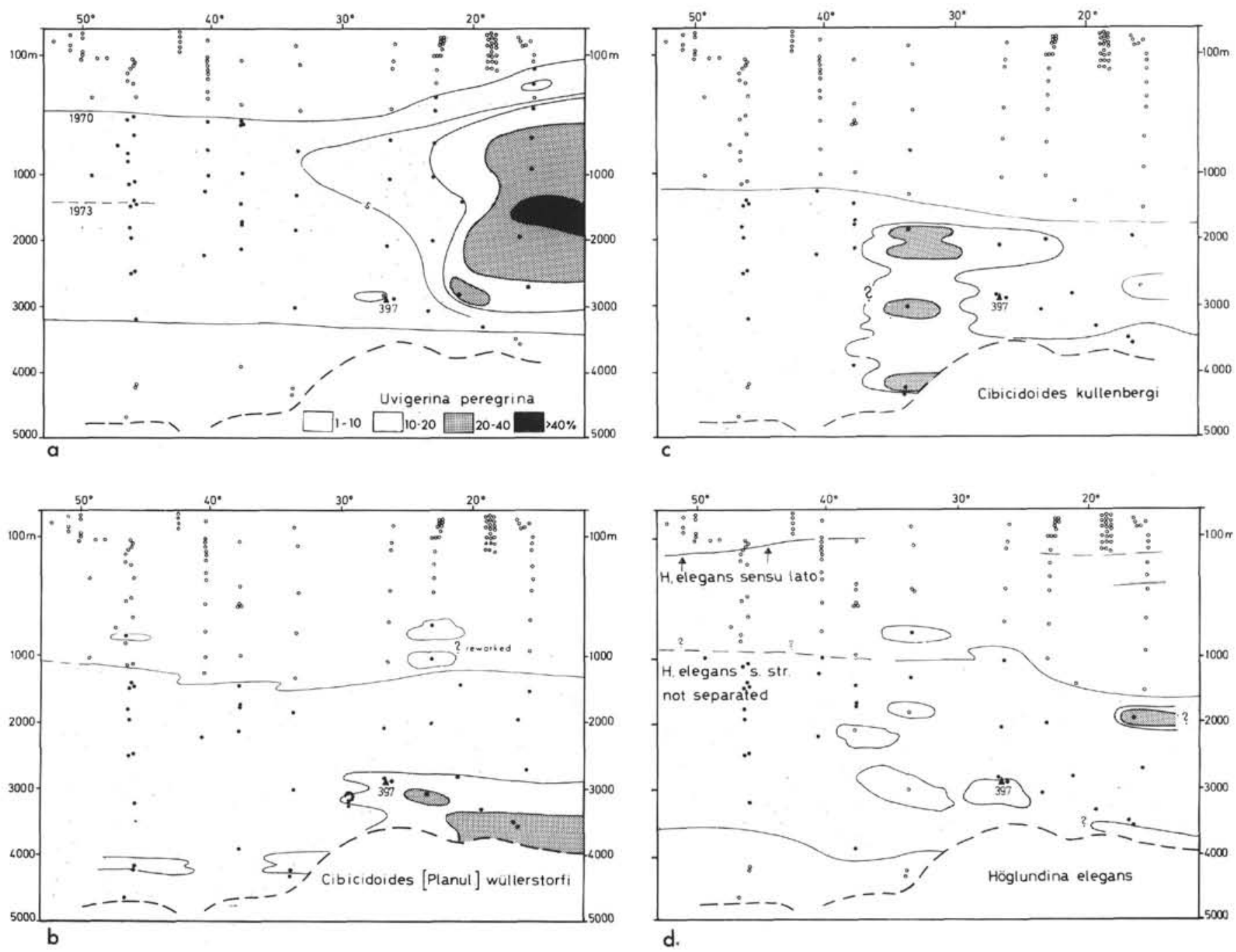

Figure 6 (a-d). Depth distribution of dominant species in modern surface sediments at the eastern North Atlantic slope and rise. Per cent of the death assemblage larger than $250 \mu \mathrm{m}$. The diagrams are part of a detailed study on depth ranges off West Africa (Lutze, Mascr.). Stations north of $45^{\circ} \mathrm{N}$ refer to literature (Pujos-Lamy, 1973; Caralp et al., 1970). Note the vertically shaped pattern of distribution in Figure $6 a$ and $6 c$. 
WARM SPECIES

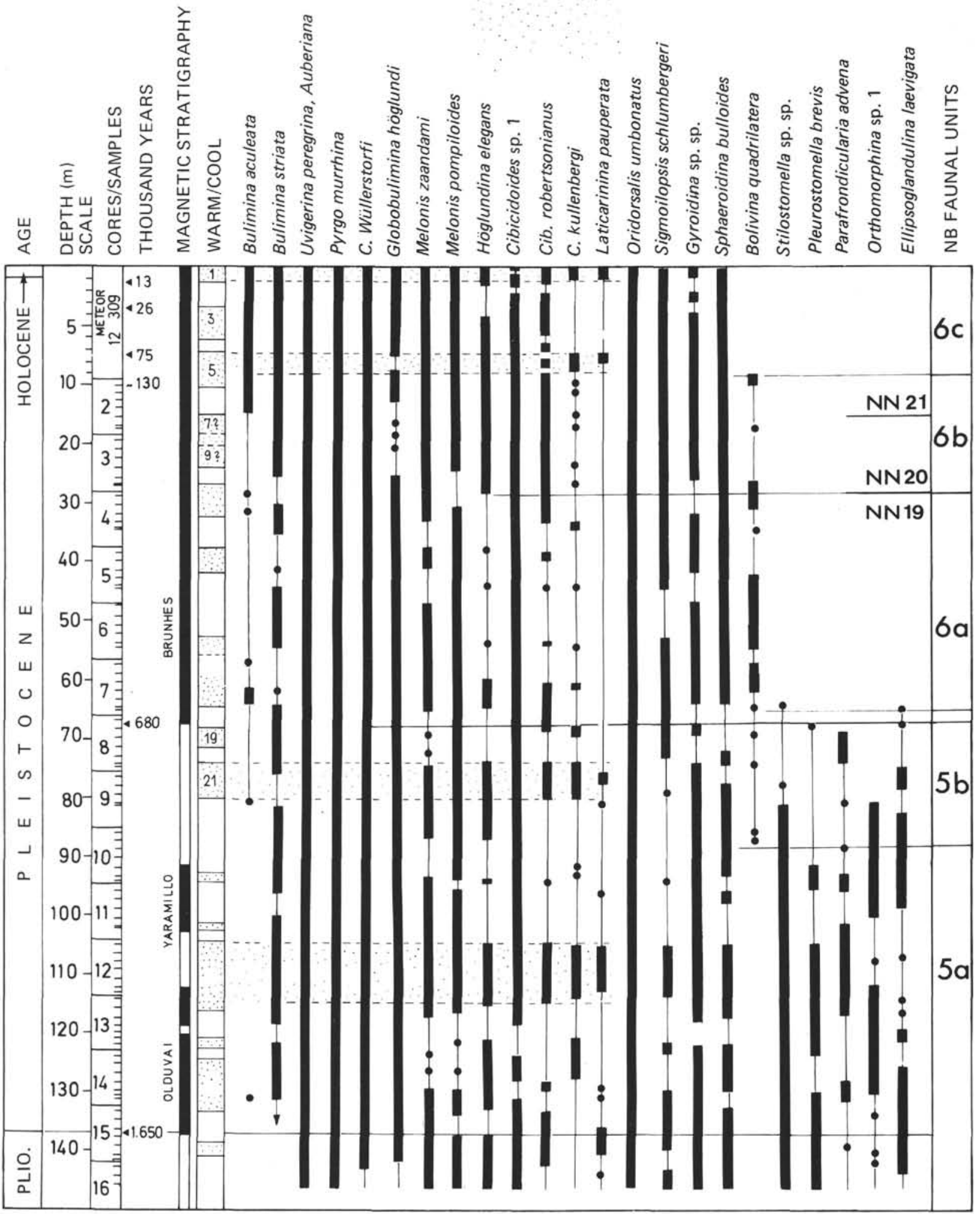

Figure 7. Ranges of dominant benthic foraminifers of the fraction $250 \mu \mathrm{m}$. The occurrence of several "warm" species (e.g., C. kullenbergi, C. robertsonianus, Laticarinina pauperata) is often restricted to warm phases (stippled intervals). The species numbers refer to the figures given on Plate 1 through 3. Nannofossil boundaries are given in the upper right, according to Cepek this volume. Magnetic stratigraphy according to Hamilton, this volume. 


\section{PLATE 1}

Figure 1 Bulimina aculeata Orbigny, 1926. SEM, Sample $397-4$, 3-61 cm, size $0.45 \mathrm{~mm}$.

Figure 2 Bulimina striata Orbigny, 1843. SEM, Sample $397-3,5-75 \mathrm{~cm}$, size $0.65 \mathrm{~mm}$. Some authors use the name $B$. costata.

Figure $3 b \quad$ Uvigerina peregrina Cushman, 1923. SEM, Sample $397-11,5-69 \mathrm{~cm}$, sizes $0.57 \mathrm{~mm}$ and $0.82 \mathrm{~mm}$.

Figures 4a, 4b, Pyro murrhina (Schwager, 1886). Sample 397-4, 3-61 cm, sizes $1.35 \mathrm{~mm}$.

4a. SEM, apertural detail.

4b. Light microscope.

Figures 5a, 5b Cibicidoides wuellerstorfi (Schwager, 1866). Sample 397-6, 2-69 cm.

5a. SEM.

5b. Light microscope. Sizes $0.75 \mathrm{~mm}$ and $0.7 \mathrm{~mm}$. placed in the genus Planulina; see Parker, 1964, p. 624.

Figure 6 Globobulimina hoeglundi Uchio, 1960. SEM, Sample 397-5, 3-69 cm, size $0.77 \mathrm{~mm}$. Several authors referred to this species to G. affinis (Orbigny). I prefer Uchio's name because it appears to be more precisely defined and topotypes are at hand.

Figure 7 Melonis zandami (Voorthuysen, 1952). SEM, Sample $397-10,7-? \mathrm{~cm}$, size $0.45 \mathrm{~mm}$. Originally referred to Anomalinoides. (For details, see Loeblich and Tappan, 1953, Artic Foraminifera.) Most authors refer to this species to $M$. baarleanum. 


\section{PLATE 1}
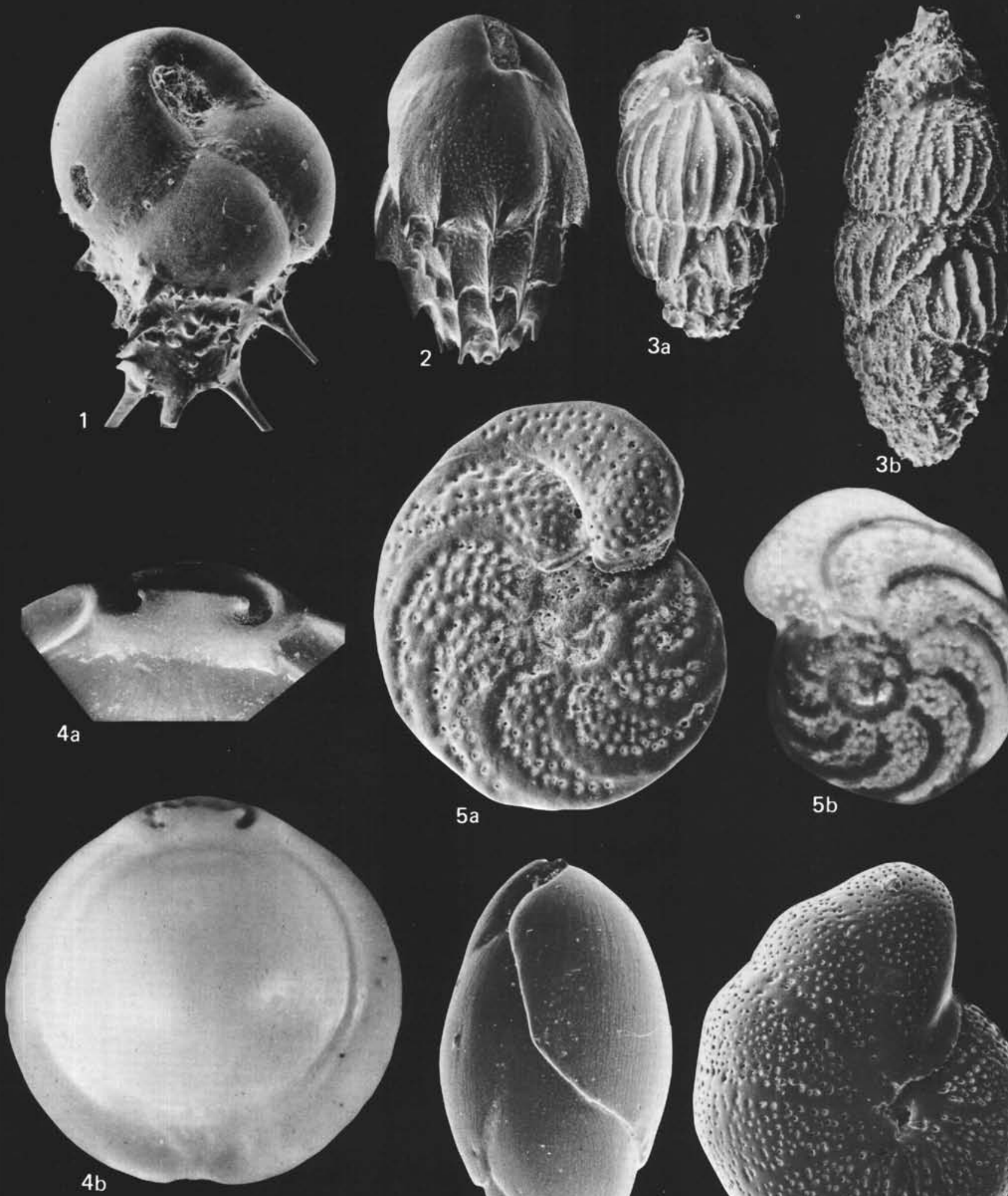

$5 a$
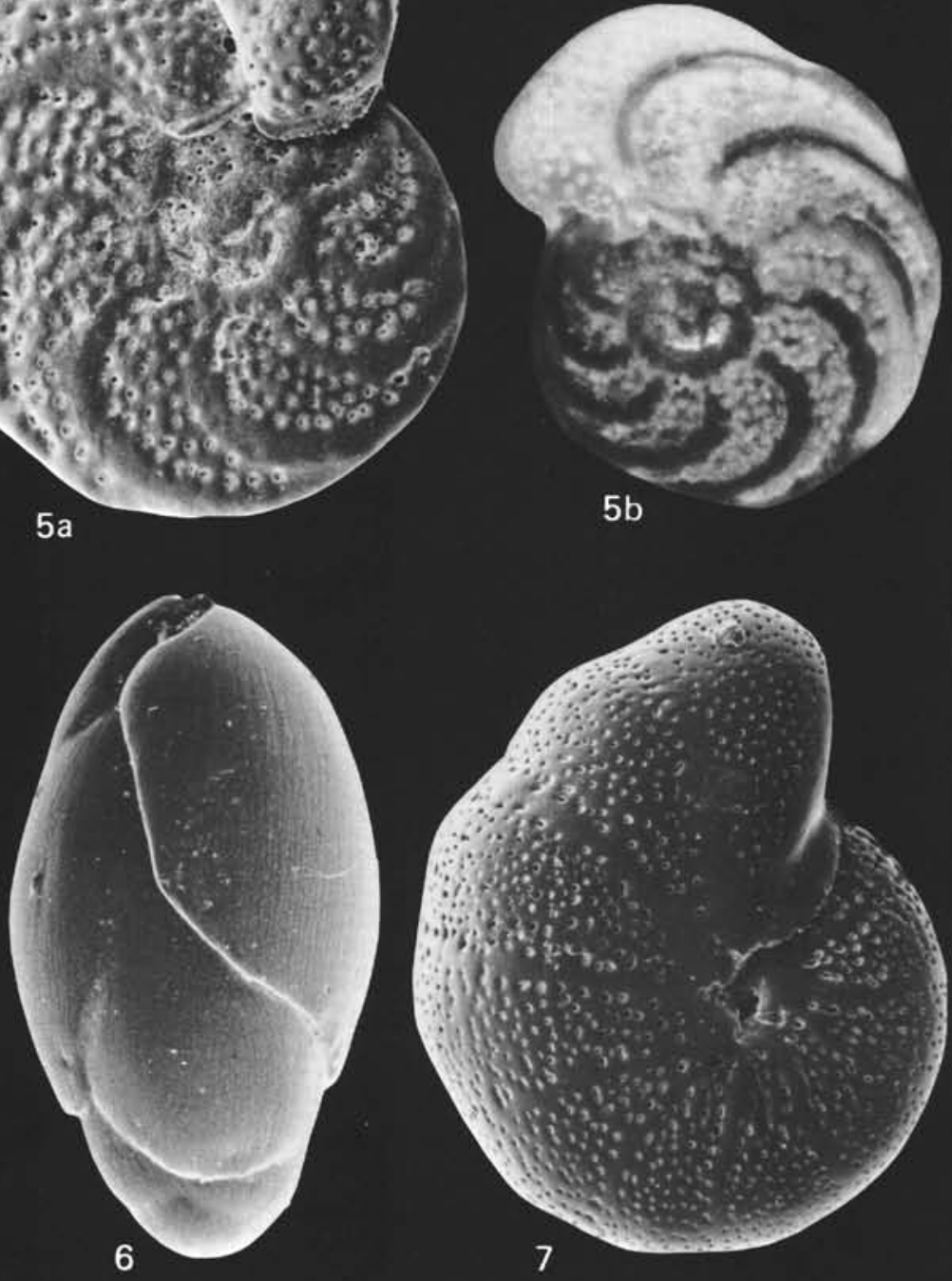


\section{PLATE 2}

Figures 1a, 1b Melonis pompilioides (Fichtel and Moil, 1798).

1a. SEM.

1b. Light microscope, apertural face. Sample $397-7,4-70 \mathrm{~cm}$, sizes $0.42 \mathrm{~mm}$ and $0.525 \mathrm{~mm}$.

Figures 2a, 2b Hoeglundina elegans (Orbigny 1826).

2a. SEM, umbilical side.

2b. Spiral side, light microscope, Sample 397-2, $6-40 \mathrm{~cm}$, sizes $1.17 \mathrm{~mm}$ and $0.87 \mathrm{~mm}$.

Figures 3a, 3b Cibicidoides sp. 1, SEM.

3a. Spiral side, Sample $397-7,4-70 \mathrm{~cm}$, size $0.57 \mathrm{~mm}$.

3b. Umbilical side, Sample 397-3-4-87 cm, size $0.5 \mathrm{~mm}$.

Figures 4a, 4b Cibicidoies robertsonianus (Brady, 1881).

4a. Light microscope, spiral side.

4b. SEM, spiral side, Sample 397-4, 3-61 cm, sizes $0.82 \mathrm{~mm}$ and $0.57 \mathrm{~mm}$.

Figures 5a, 5b Cibicidoides kullenbergi Parker, 1953.

5a. SEM, Sample 397-3, 4-87 cm, size $0.52 \mathrm{~mm}$.

5 b. Light microscope, Sample 397-9, 1-35 cm, size $0.6 \mathrm{~mm}$. Both figures show spiral side.

Figure 6 Laticarinina pauperata (Parker and Jones, 1865). Light microscope, Sample from Meteor Core $12309-2,20 \mathrm{~cm}$, size $1.75 \mathrm{~mm}$.

Figure $7 \quad$ Oridorsalis umbonatus (Reuss, 1851).

Sample $397-13,2-70 \mathrm{~cm}$, size $0.5 \mathrm{~mm}$. 


\section{PLATE 2}
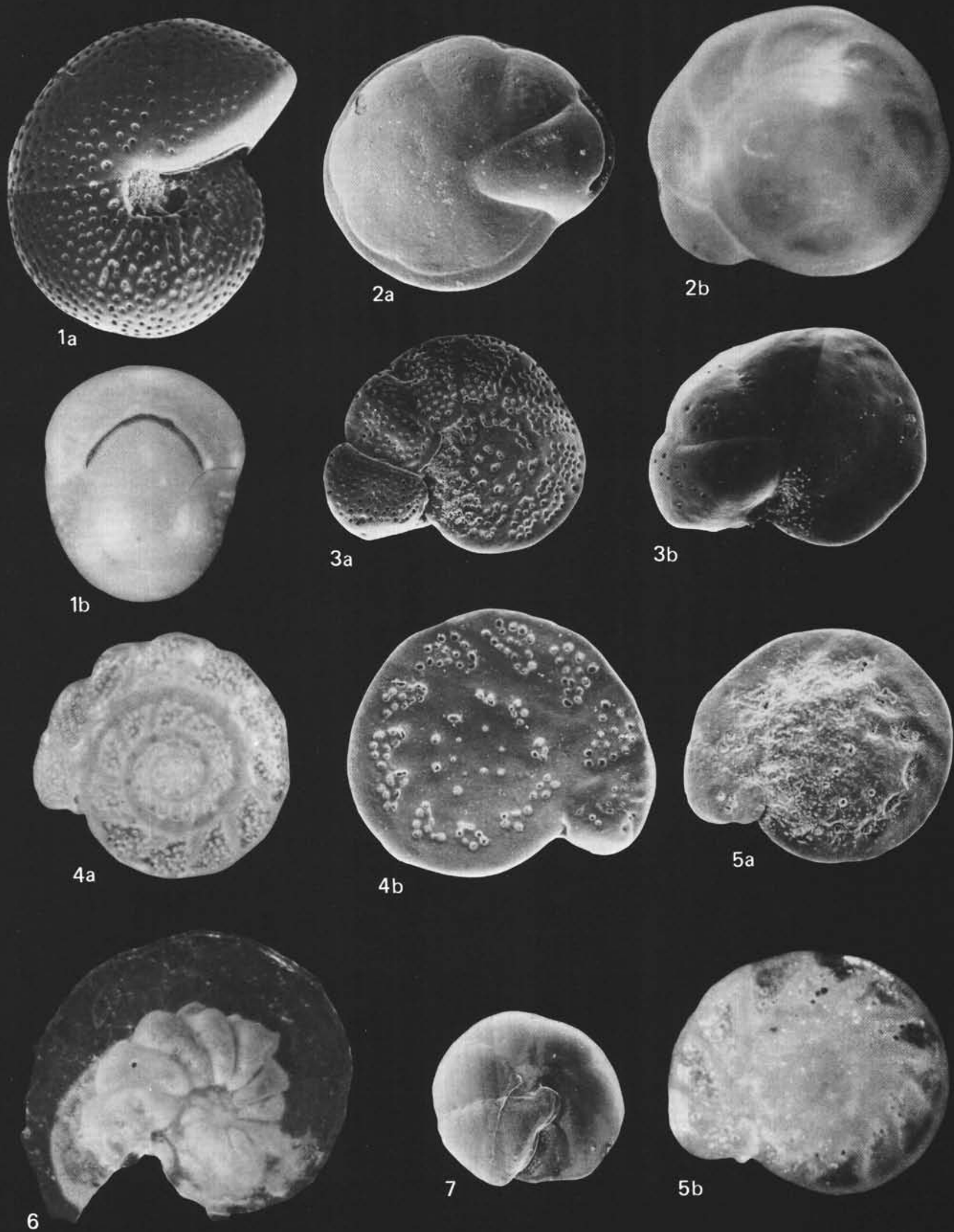


\section{PLATE 3}

Figure 1

Figure 2

Figure 3

Figures $4 \mathrm{a}, 4 \mathrm{~b}$

Figure 5

Figures $6 \mathrm{a}, 6 \mathrm{~b}$

Figure 7
Sigmoilopsis schlumbergeri (Silvestri,1904). SEM, Sample 397-7, 4-70 cm, size $0.72 \mathrm{~mm}$.

Sphaeroidina bulloides Orbigny, 1826. Light microscope, Sample 397-6, 5-71 cm, size 0.87 mm.

Bolivina quadrilatera (Schwager, 1866). SEM, Sample 397-4, 1-69 cm, size $0.95 \mathrm{~mm}$.

Pleurostomella brevis (Schwager, 1866). SEM, Samples 397-12, 1-70 cm and 397-12, 5-70 cm, sizes $0.67 \mathrm{~mm}$ and $0.85 \mathrm{~mm}$. The name was used in a rather wide sense. SEM studies of apertural details of various Pleurostomella species are required to enable a more exact identification and the separation of different taxons.

Parafrondicularia advena (Cushman, 1923). SEM, Sample 397-8, 3-67 cm, size $1.3 \mathrm{~mm}$.

Orthomorphina? sp. SEM,

Sample 397-10, 1-70 cm; sizes $1.0 \mathrm{~mm}$ and 1.92 $\mathrm{mm}$. Specimens with larger spines (Figure 20A) and those with small spines, nearly invisible under the light microscope (Figure 26B), were counted together. Close to Orthomorphina? fistuca (Schwager, 1866).

Ellipsoglandulina laevigata Schwager. 1900, light microscope, Sample 369-2, 5-60 cm, Pliocene, size $1.3 \mathrm{~mm}$. 
PLATE 3

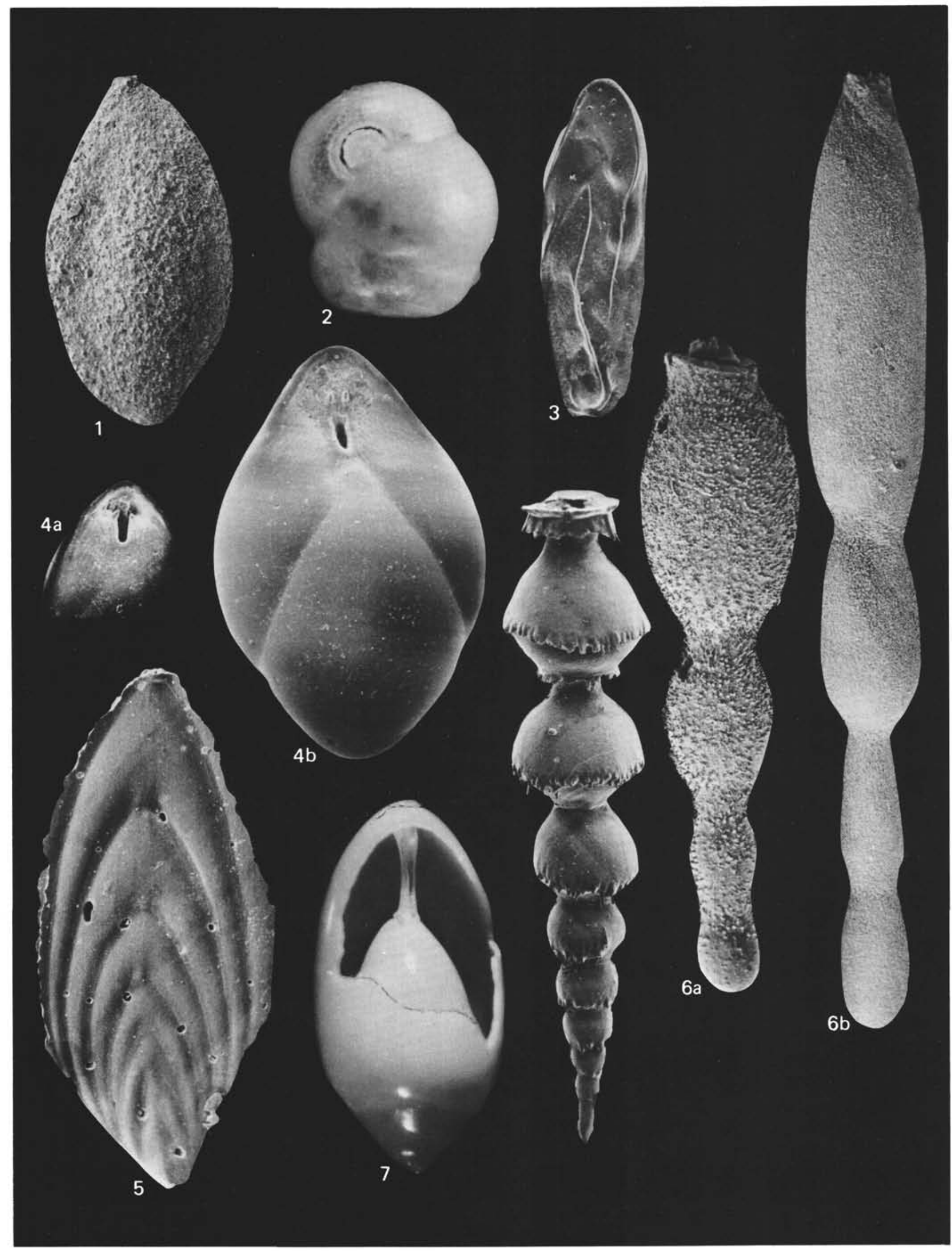

